\title{
Rg1 protects rat bone marrow stem cells against hydrogen peroxide-induced cell apoptosis through the PI3K/Akt pathway
}

\author{
JUNZHENG HU, YANQING GU and WEIMIN FAN
}

Department of Orthopedics, The First Affiliated Hospital of Nanjing Medical University, Nanjing, Jiangsu 210000, P.R. China

Received May 19, 2015; Accepted March 1, 2016

DOI: $10.3892 / \mathrm{mmr} .2016 .5238$

\begin{abstract}
The aim of the present study was to investigate the protective mechanism of ginsenoside Rg1 against the apoptosis of rat bone marrow stem cells (rBMSCs) under oxidative stress, and to determine the association with the phosphoinositide 3-kinase (PI3K)/protein kinase $\mathrm{B}$ (Akt) pathway. $\mathrm{H}_{2} \mathrm{O}_{2}$ was used to induce oxidative injury in rBMSCs. The cells in the $\mathrm{H}_{2} \mathrm{O}_{2}$ model group were treated with $800 \mu \mathrm{M} \mathrm{H}_{2} \mathrm{O}_{2}$ for $6 \mathrm{~h}$ to induce oxidative injury. The cells in the ginsenoside $\mathrm{Rg} 1$ group were treated with $10 \mu \mathrm{M}$ ginsenoside $\mathrm{Rg} 1$ for $24 \mathrm{~h}$, followed by $\mathrm{H}_{2} \mathrm{O}_{2}$ treatment. The cells in the Akt pathway blockage group were treated with $25 \mu \mathrm{M}$ LY294002 for $1 \mathrm{~h}$, followed by ginsenoside $\mathrm{Rg} 1+\mathrm{H}_{2} \mathrm{O}_{2}$ treatment. The cell counting kit- 8 assay was performed to determine cell viability. Cell apoptosis was detected by flow cytometry and terminal deoxynucleotidyl transferase dUTP nick end labeling (TUNEL) staining. The results of flow cytometry and TUNEL staining indicated that the apoptotic rate of the $\mathrm{H}_{2} \mathrm{O}_{2}$ model group was significantly higher compared with that of the control group. Following the ginsenoside Rg1 pretreatment, the apoptotic rate was significantly reduced. In the Akt pathway blockage group, no significant alterations in the levels of cell apoptosis were observed compared with the $\mathrm{H}_{2} \mathrm{O}_{2}$ model group. Western blot analysis demonstrated that the ginsenoside Rg1 group had a significant downregulation of Bax and cleaved caspase-3 and an upregulation of $\mathrm{Bcl}-2$ and phosphorylated Akt protein expression levels compared with the $\mathrm{H}_{2} \mathrm{O}_{2}$ model group and the Akt pathway blockage group. In conclusion, ginsenoside $\mathrm{Rg} 1$ had a protective effect against the $\mathrm{H}_{2} \mathrm{O}_{2}$-induced oxidative stress of rBMSCs, and the specific mechanism may be associated with the activation of the PI3K/Akt pathway by ginsenoside $\operatorname{Rg} 1$.
\end{abstract}

Correspondence to: Professor Weimin Fan, Department of Orthopedics, The First Affiliated Hospital of Nanjing Medical University, 300 Guangzhou Road, Nanjing, Jiangsu 210000, P.R. China

E-mail: fanweimin@vip.sina.com

Key words: ginsenoside Rg1, apoptosis, bone marrow stem cells

\section{Introduction}

Bone marrow stem cells (BMSCs) are considered as the best 'seeds' in cell replacement therapy (CRT) and tissue engineering due to their strong differentiation potential, easy availability and amplification, and absence of rejection in autotransfusion. BMSCs have wide applications in bone and cartilage reconstruction $(1,2)$ and the repair and therapy of bone marrow injury (3), hypoxic-ischemic nerve cells (4) and myocardial cells $(5,6)$. Previous studies have demonstrated that the growth and differentiation potential may be affected either due to the accumulation of reactive oxygen species (ROS) in the region of BMSCs transplantation caused by ischemic injury (7) or due to the increased level of ROS resulting from natural aging or estrogen deficiency $(8,9)$. Therefore, the effect of BMSCs transplantation in CRT and tissue engineering is greatly impaired.

Elevation of ROS levels is the major reason for mitochondrial swelling, decline of mitochondrial membrane potential, calcium overload and the release of precursor proteins in mitochondrial death pathway $(10,11)$. Oxidative stress leads to apoptotic injury in BMSCs. Therefore, the improvement of the survival of BMSCs in the transplantation region by anti-oxidative and anti-apoptotic therapies is key to the success of CRT and tissue engineering.

Previous studies indicated that estrogen antagonizes the apoptosis of BMSCs under oxidative stress by protecting the mitochondrial membrane integrity (12-14). Phytoestrogen possesses estrogen-like activity and exhibits the function of clearing free radicals and anti-oxidative effects in cellular experiments $(15,16)$. Ginsenoside $\mathrm{Rg} 1$ is a representative monomer in panaxatriol saponins and the primary active compound in ginseng. As a type of phytoestrogen, ginsenoside Rg1 demonstrates anti-aging, anti-oxidative and anti-apoptotic abilities in nerve and cardiovascular cells (17-20). The present study hypothesized that ginsenoside Rg1 may antagonize the apoptosis of BMSCs under oxidative stress by protecting mitochondrial membrane integrity.

The phosphatidylinositol-3 kinase/protein kinase B (PI3K/Akt) pathway is one of the primary signal transduction pathways inhibiting cell apoptosis and promoting cell survival (21). The PI3K/Akt pathway has an anti-apoptotic effect via the phosphorylation of downstream protein Bad and the activation of B-cell lymphoma 2 (Bcl-2) (22). Previous studies demonstrated that activation of the PI3K/Akt 
pathway regulates the $\mathrm{H}_{2} \mathrm{O}_{2}$-induced apoptosis of rat BMSCs (rBMSCs) (23-27). The current study hypothesized that the antagonistic effect of ginsenoside $\mathrm{Rg} 1$ against the apoptosis of BMSCs induced by oxidative stress may be associated with the activation of the PI3K/Akt pathway.

A model of $\mathrm{H}_{2} \mathrm{O}_{2}$-induced oxidative injury in rBMSCs was developed in order to verify the above hypothesis. The protective effect of ginsenoside $\mathrm{Rg} 1$ against $\mathrm{H}_{2} \mathrm{O}_{2}$-induced oxidative injury in rBMSCs was observed. In addition, the possible associations with the PI3K/Akt pathway were investigated to understand the application of BMSCs in CRT and tissue engineering.

\section{Materials and methods}

Materials. Healthy female Sprague-Dawley rats $(n=10$, weight, $180 \pm 20 \mathrm{~g}$; age, 4 weeks) were provided by Nanjing Medical University (Jiangsu, China). Ginsenoside Rg1 was purchased from Shanghai Oriental Pharmaceutical Co., Ltd. (Shanghai, China). Gibco low-glucose Dulbecco's modified Eagle's medium (DMEM), fetal bovine serum (FBS) and trypsin were purchased from Thermo Fisher Scientific, Inc. (Waltham, MA, USA). The Cell Counting Kit-8 (CCK-8) assay kit was supplied by Dojindo Laboratories (Kumamoto, Japan) and polyvinylidene fluoride membrane by Roche Diagnostics (Basel, Switzerland). Bax, Bcl-2, phosphorylated (p)-Akt and Akt primary antibodies were purchased from Cell Signaling Technology, Inc. (Danvers, MA, USA). This study was approved by the ethics committee of Nanjing Medical University.

Isolation, culture and identification of rBMSCs. The rats were sacrificed by cervical dislocation and soaked in $70 \%$ alcohol for $20 \mathrm{~min}$. The tibia and femur were harvested under aseptic conditions, and the diaphysis was severed using sterilized ophthalmic scissors. The marrow cavity was flushed repeatedly with phosphate-buffered saline (PBS; Hyclone, Logan, UT, USA) solution, and then transferred to a centrifuge tube for centrifugation for $5 \mathrm{~min}$ at $120 \mathrm{x}$ g for $5 \mathrm{~min}$. The supernatant was discarded, and the precipitate was resuspended in $85 \%$ low-glucose DMEM [15\% FBS + penicillin/streptomycin (Hangzhou Sijiqing Biological Engineering Materials, Co., Ltd., Hangzhou, China)]. The cells were then seeded at $1 \times 10^{6}$ cells $/ \mathrm{cm}^{2}$ and cultured in a $37^{\circ} \mathrm{C}, 5 \% \mathrm{CO}_{2}$ incubator. Half a volume of the medium was replaced $24 \mathrm{~h}$ later, and the full volume was replaced 2-3 days later. When the cells reached $80 \%$ confluency, they were passaged by digestion using $0.25 \%$ trypsin. The cells of the third generation were collected to detect purity and were free from the non-adherence spherocytes, thus the purified rBMSCs were obtained.

Determination of final concentrations of $\mathrm{H}_{2} \mathrm{O}_{2}$ and ginsenoside Rg1 using the CCK-8 assay. rBMSCs of the third generation were prepared into $1 \times 10^{5}$ cells $/ \mathrm{ml}$ single-cell suspension and seeded to 96 -well plates $\left(10^{4}\right.$ cells/well $)$. Following cell adherence to the wall of the plate, the cells were starved for $24 \mathrm{~h}$ by adding $100 \mu \mathrm{l}$ serum-free culture medium. Five wells were randomly selected, and culture media containing different concentrations of $\mathrm{H}_{2} \mathrm{O}_{2}$ (0, 200, 400, 600 and $800 \mu \mathrm{M}$; Beijing Haiderun (Sea Derun)
Pharmaceutical Co., Ltd., Beijing, China) was added to treat the cells for $6 \mathrm{~h}$. Cells were then incubated at $37^{\circ} \mathrm{C}$ for $30 \mathrm{~min}$ with $10 \mu \mathrm{l}$ CCK- 8 solution. The absorbance was measured at 450 nm (Model 680; Bio-Rad Laboratories, Inc., Hercules, CA, USA).

To determine the final concentration of $\mathrm{H}_{2} \mathrm{O}_{2}$, cells were starved for $24 \mathrm{~h}$ using the method described above and 4 wells were randomly selected. Ginsenoside Rg1 of different concentrations $(0,0.1,1$ and $10 \mu \mathrm{M})$ was added into each well to treat the cells for $24 \mathrm{~h}$, followed by $800 \mu \mathrm{M} \mathrm{H}_{2} \mathrm{O}_{2}$ treatment for $6 \mathrm{~h}$. One group was randomly selected as the control group, for which no treatment was performed. The absorbance was measured using the CCK-8 solution as described above.

Grouping. Cells of third generation reaching the logarithmic growth phase were divided into 4 groups as follows: Control, untreated; $\mathrm{H}_{2} \mathrm{O}_{2}$-treated, addition of $800 \mu \mathrm{M} \mathrm{H}_{2} \mathrm{O}_{2}$ to induce oxidative injury; ginsenoside $\mathrm{Rg} 1$-treated, $10 \mu \mathrm{M}$ ginsenoside $\mathrm{Rg} 1$ for $24 \mathrm{~h}$, followed by $800 \mu \mathrm{M} \mathrm{H}_{2} \mathrm{O}_{2}$ for $6 \mathrm{~h}$; and Akt pathway blockage group, blockage achieved by addition of $25 \mu \mathrm{M}$ LY294002 (Cell Signaling Technologies, Inc., Boston, MA, USA) for $1 \mathrm{~h}$, followed by ginsenoside Rg1 and $\mathrm{H}_{2} \mathrm{O}_{2}$ treatments.

Detection of cellular apoptotic rate by TUNEL staining. The rBMSCs of the third generation were seeded into a 24-well plate. The cells in sub-aggregation state were starved for $24 \mathrm{~h}$ using the serum-free culture medium. When the cells in each treatment were dried, they were fixed in $4 \%$ paraformaldehyde (Wuhan GoodBio Technology, Co., Wuhan, China) for $1 \mathrm{~h}$, and sealed for 10 min using the confining liquid $\left(3 \% \mathrm{H}_{2} \mathrm{O}_{2}\right.$, dissolved in methanol). Subsequent to transparentization for 2 min using 0.1\% Triton X-100 (Biosharp, Hefei, China), the cells were sealed for $1 \mathrm{~h}$ in the TUNEL reaction mixture at $37^{\circ} \mathrm{C}$ in a dark box. The cells were incubated with 4',6-diamidino-2-phenylindole (DAPI; Beyotime Institute of Biotechnology, Haimen, China) for $5 \mathrm{~min}$, and the fluorescence was detected Nikon eclipse Ti (Tokyo, Japan). TUNEL (Roche, Indianapolis, IN, USA) staining is an intuitive method to detect apoptosis. With DAPI-TUNEL double staining, the cells are counted directly, which enables the comparison of cellular apoptotic rate between the samples. The blue fluorescence indicates that the cells were stained by DAPI and the green fluorescence indicates that the cells were stained by TUNEL.

Detection of cellular apoptosis using flow cytometry and Annexin V-fluorescein isothiocyanatelpropidium iodide (FITC/PI) double staining. rBMSCs of the third generation were inoculated into a 6 -well plate. Following cell adherence to the walls of the plate, cells were divided into the 4 treatment groups. Following treatment, cells were collected and centrifuged for $5 \mathrm{~min}$ at $270 \mathrm{x}$ g. The supernatant was discarded and cells were washed twice with PBS. Cells were then resuspended in $500 \mu \mathrm{l}$ of binding buffer, and $5 \mu \mathrm{l}$ FITC-labeled Annexin V $(20 \mu \mathrm{g} / \mathrm{ml})$ and $5 \mu \mathrm{l} \mathrm{PI}(50 \mu \mathrm{g} / \mathrm{ml})$ (all from; BD PharMingen,San Diego, CA, USA) were added to the solution. The reaction was conducted in the dark for 15 min, and cell apoptosis was detected by BD FACS ARIA II flow cytometry (BD Biosciences, San Jose, CA, USA). 
A

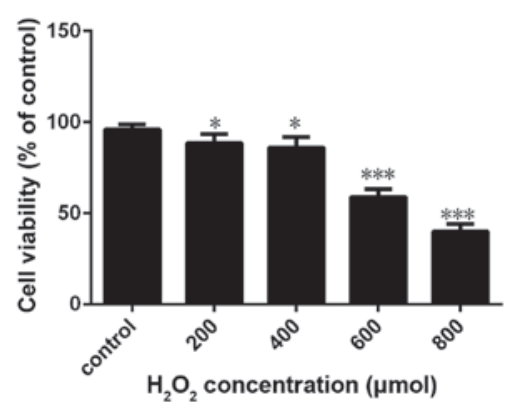

B

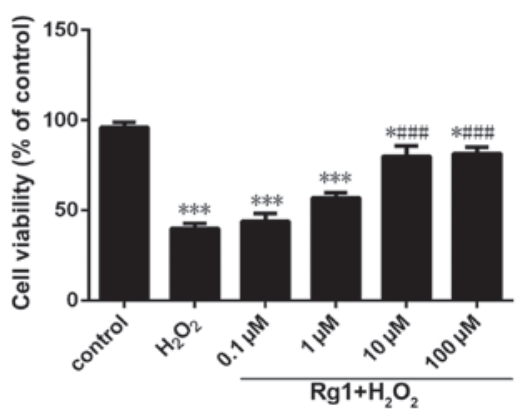

Figure 1. Effect of different concentrations of $\mathrm{H}_{2} \mathrm{O}_{2}$ and $\mathrm{Rg} 1+\mathrm{H}_{2} \mathrm{O}_{2}$ treatment on the cell viability of rat bone marrow stem cells under oxidative stress. (A) $\mathrm{H}_{2} \mathrm{O}_{2}$ treatment $(200,400,600$ and $800 \mu \mathrm{M})$ for $6 \mathrm{~h}$ resulted in a significant reduction of cell viability compared with the control group in a dose-dependent manner. A significant reduction in cell viability was demonstrated in the treated groups, except in the 200 and $400 \mu \mathrm{M}$-treated groups. The cell survival rate approached $50 \%$ in the $600 \mu \mathrm{M}$-treated group. (B) The cell viability of $\mathrm{H}_{2} \mathrm{O}_{2}$ model group was significantly reduced compared with the control group $(\mathrm{P}<0.05)$. The cell viability significantly increased following 10 and $100 \mu \mathrm{M}$ Rg1 treatment, compared with the $\mathrm{H}_{2} \mathrm{O}_{2}$ model group. There was no statistically significant difference in cell viability between the 10 and $100 \mu \mathrm{M} \mathrm{Rg1-treated} \mathrm{groups}(\mathrm{P}>0.05)$. ${ }^{* * *} \mathrm{P}<0.05$ vs. the control group and ${ }^{\# \# \#} \mathrm{P}<0.05$ vs. the $\mathrm{H}_{2} \mathrm{O}_{2}$ model group. ${ }^{*} \mathrm{P}>0.05$ vs. the control group. Data are presented as the mean \pm standard deviation for three independent experiments. $\mathrm{H}_{2} \mathrm{O}_{2}$, hydrogen peroxide; $\operatorname{Rg} 1$, ginsenoside $\operatorname{Rg} 1$.

Detection of p-Akt, Bcl-2, Bax and cleaved caspase-3 protein expression levels by western blotting. Western blotting was conducted to detect apoptosis-associated proteins and $\mathrm{p}-\mathrm{Akt}$ levels in $\mathrm{H}_{2} \mathrm{O}_{2}$-treated $\mathrm{rBMSCs}$ with $\mathrm{Rg} 1$ pretreatment. Subsequent to each treatment, cells were washed twice with PBS, and the pre-cooled cell lysis buffer was added. The reaction proceeded on ice for $5 \mathrm{~min}$ and the cells were then scraped off. The products of lysis were centrifuged for $15 \mathrm{~min}$ at $4^{\circ} \mathrm{C}$ at $14,000 \mathrm{x}$. The supernatant was collected to determine the protein concentration using the Bicinchoninic Acid assay kit (Beyotime Institute of Biotechnology). Equal quantities of protein sample were subjected to $10 \%$ sodium dodecyl sulfate-polyacrylimide gel electrophoresis $80 \mathrm{~mA}$ for first $30 \mathrm{~min}$ then $120 \mathrm{~mA}$ for last $90 \mathrm{~min}$ (Beyotime Institute of Biotechnology). Following electrophoresis, proteins were transferred to a nitrocellulose membrane (Biosharp), which was sealed with $5 \%$ nonfat milk powder containing $0.05 \%$ Tween-20 with Tris-buffered saline (TBST; Biosharp) at room temperature for $1 \mathrm{~h}$. The membranes were then incubated with the following antibodies: Rabbit anti-p-Akt (1:1,000; cat. no.\#9271), polyclonal anti-Akt (1:1,000; cat. no. \#9272), polyclonal anti-Bcl-2 (1:1,000; cat. no. \#2876), polyclonal anti-Bax (1:1,000; cat. no. \#2772) and monoclonal anti-caspase-3, (1:1,000; cat. no. \#9665) (all from Cell Signaling Technologies, Inc.) primary antibodies at $4^{\circ} \mathrm{C}$ overnight. Membranes were washed 3 times with TBST for $15 \mathrm{~min}$, incubated with goat anti-rabbit horseradish peroxidase-labeled secondary antibodies (1:2,000; cat. no. \#7074; Cell Signaling Technologies, Inc.) for $2 \mathrm{~h}$, followed by 3 washes with TBST for $10 \mathrm{~min}$. Enhanced chemiluminescence (Thermo Fisher Scientific, Inc.) was utilized to visualize the proteins. Images were captured using an imaging system (UVP Inc., Upland, CA, USA). The images were analyzed using Image Lab software v2.0.1 (Bio-Rad Laboratories, Inc.). The ratio of absorbance of the target band to that of the glyceraldehyde 3 -phosphate dehydrogenase band was used to measure the expression level of the proteins.

Statistical analysis. All statistical processes were performed using SPSS software, version 13.0 (SPSS, Inc., Chicago,
IL, USA). The measurement data were expressed as the mean \pm standard deviation. One-way analysis of variance was adopted for intergroup comparison. $\mathrm{P}<0.05$ was considered to indicate a statistically significant difference.

\section{Results}

Effect of various concentrations of $\mathrm{H}_{2} \mathrm{O}_{2}$ on the cell viability of rBMSCs. As demonstrated in Fig. 1, subsequent to $6 \mathrm{~h}$ of $\mathrm{H}_{2} \mathrm{O}_{2}$ treatment, the cell viability was significantly reduced compared with the control group in a dose-dependent manner. Except 200 and $400 \mu \mathrm{M}$ group, the reduction of cell viability in all groups had a statistical significance compared with the control group $(\mathrm{P}<0.05)$. In the $600 \mu \mathrm{M}$ group, the cell survival rate approached $50 \%$ (Fig. 1A).

Effect of various concentrations of ginsenoside Rgl on the rBMSC viability under oxidative stress. Compared with the control group, the $\mathrm{H}_{2} \mathrm{O}_{2}$ model group demonstrated a significant reduction in cell viability $(\mathrm{P}<0.05)$. The cell viability of 10 and $100 \mu \mathrm{M}$ ginsenoside $\mathrm{Rg} 1$ groups increased considerably compared with the $\mathrm{H}_{2} \mathrm{O}_{2}$ model group with statistical significance $(\mathrm{P}<0.05)$. There was no significant difference in cell viability between $10 \mu \mathrm{M}$ group and $100 \mu \mathrm{M}$ group $(\mathrm{P}>0.05)$ (Fig. 1B)

Detection of apoptotic rate of rBMSCs by flow cytometry. The results of flow cytometry for each treatment indicated that the apoptosis rate of the $\mathrm{H}_{2} \mathrm{O}_{2}$ model group increased significantly compared with the control group (from $3.92 \pm 0.128$ in the control to $59.44 \pm 3.21 \%$; Fig. $2 ; \mathrm{P}<0.05$ ). The apoptotic ratio following $\mathrm{H}_{2} \mathrm{O}_{2}+\mathrm{Rg} 1$ treatment was significantly reduced to $33.41 \pm 4.88 \%$ compared with the $\mathrm{H}_{2} \mathrm{O}_{2}$ model group $(59.44 \pm 3.21 \%)$ and $\mathrm{H}_{2} \mathrm{O}_{2}+\mathrm{Rg} 1+\mathrm{LY} 294002$ group (49.64 $\pm 2.33 \%$; Fig. 2; $\mathrm{P}<0.05$ ).

Detection of apoptosis of rBMSCs by TUNEL staining. Following TUNEL staining, the positive percentage of the $\mathrm{H}_{2} \mathrm{O}_{2}$ model group demonstrated a significant increase 
A
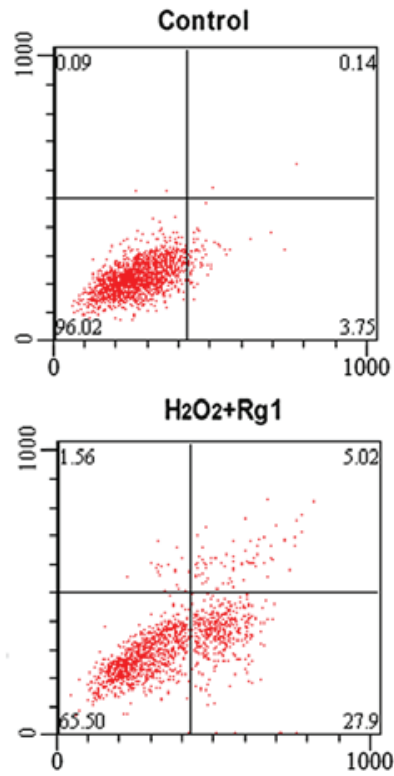
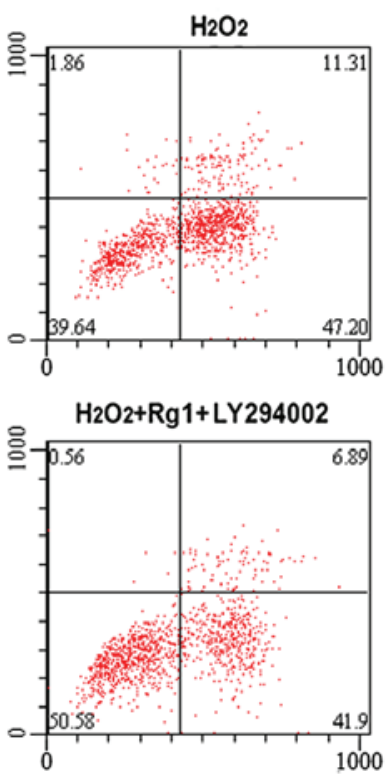

B

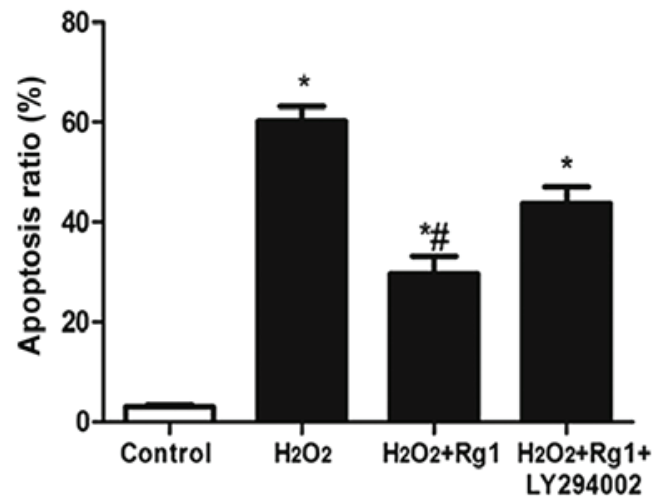

Figure 2. Detection of the apoptotic rate in rat bone marrow stem cells using flow cytometry. (A) Flow cytometry indicated that the apoptotic rate of the $\mathrm{H}_{2} \mathrm{O}_{2}$ model group increased from $3.92 \pm 0.128$ to $59.44 \pm 3.21 \%$. The apoptotic rate of the Rg1-treated group (10 $\left.\mu \mathrm{M}\right)$ was significantly reduced to $33.41 \pm 4.88 \%$ compared with the $\mathrm{H}_{2} \mathrm{O}_{2}$ and LY294002-treated groups. (B) Histogram indicating the apoptotic rate in the control, $\mathrm{H}_{2} \mathrm{O}_{2}, \mathrm{H}_{2} \mathrm{O}_{2}+\mathrm{Rg} 1$ and $\mathrm{H}_{2} \mathrm{O}_{2}+\mathrm{Rg} 1+\mathrm{LY} 294002$-treated cells. Data represent the mean \pm standard error of the mean $(\mathrm{n}=3)$. ${ }^{*} \mathrm{P}<0.05$ vs. the control group and ${ }^{*} \mathrm{P}<0.05$ vs. the $\mathrm{H}_{2} \mathrm{O}_{2}$ model group. $\mathrm{H}_{2} \mathrm{O}_{2}$, hydrogen peroxide; $\mathrm{Rg} 1$, ginsenoside $\mathrm{Rg} 1$.

A

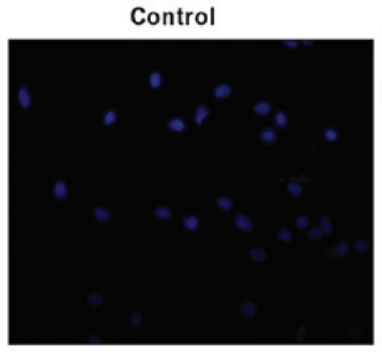

$\mathrm{H}_{2} \mathrm{O} 2+\mathrm{Rg} 1$

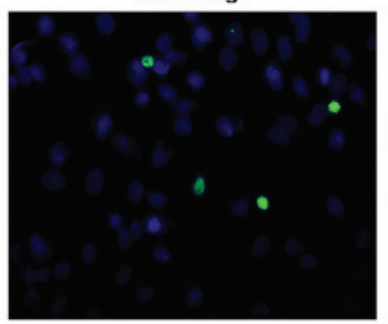

$\mathrm{H}_{2} \mathrm{O} 2$

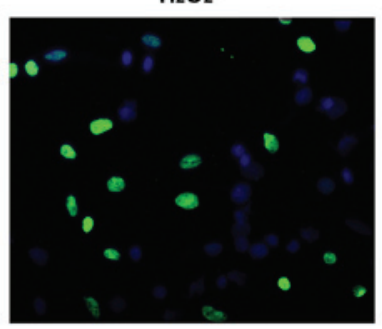

$\mathrm{H}_{2} \mathrm{O}_{2}+\mathrm{Rg} 1+\mathrm{LY} 294002$

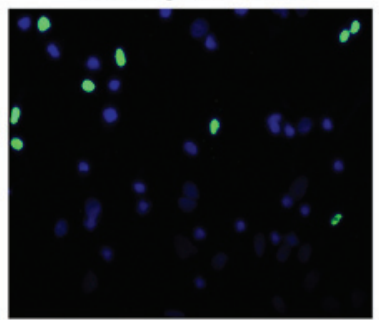

B

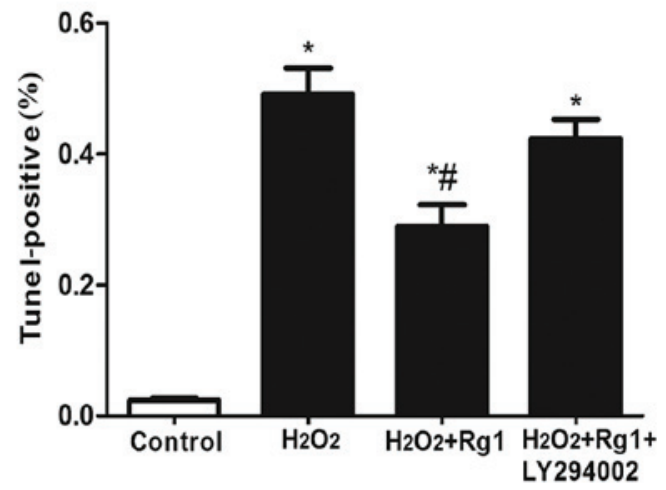

Figure 3. Detection of cell apoptosis in rat bone marrow stem cells using TUNEL staining. (A) DAPI-TUNEL double staining, blue fluorescence indicates DAPI staining and green indicates TUNEL staining. (B) Quantification of apoptotic rate. The results demonstrated a significant increase in the apoptotic rate of the $\mathrm{H}_{2} \mathrm{O}_{2}$ model group compared with the control group $(1.88 \pm 0.133-48 \pm 4.65 \% ; \mathrm{P}<0.05)$. The apoptotic rate of the Rg1-treated $(10 \mu \mathrm{M})$ group was reduced compared with that of the $\mathrm{H}_{2} \mathrm{O}_{2}$ model group $(25.29 \pm 4.33 \% ; \mathrm{P}<0.05)$. Compared with the Rg1-treated (10 $\left.\mu \mathrm{M}\right)$ group, the apoptotic rate significantly increased in the LY294002-treated group $(38.42 \pm 2.46 \%$; $\mathrm{P}<0.05)$. Data are presented as the mean \pm standard error of the mean $(\mathrm{n}=3)$. ${ }^{*} \mathrm{P}<0.05$ vs. the control group and ${ }^{\#} \mathrm{P}<0.05$ vs. the $\mathrm{H}_{2} \mathrm{O}_{2}$ model group. TUNEL, terminal deoxynucleotidyl transferase dUTP nick end labeling; DAPI, 4',6-diamidino-2-phenylindole; $\mathrm{H}_{2} \mathrm{O}_{2}$, hydrogen peroxide; $\mathrm{Rg} 1$, ginsenoside $\mathrm{Rg} 1$.

compared with the control group $(1.88 \pm 0.133-48 \pm 4.65 \%$; Fig. 3; $\mathrm{P}<0.05)$. The $\mathrm{H}_{2} \mathrm{O}_{2}+\mathrm{Rg} 1$ group demonstrated a significantly decreased TUNEL-positive percentage compared with the $\mathrm{H}_{2} \mathrm{O}_{2}$ model group (25.29 \pm 4.33\%; Fig. 3; $\mathrm{P}<0.05)$. The difference was also significant $(\mathrm{P}<0.05)$. The percentage of TUNEL-positive cells in the Akt pathway the blockage group $(38.42 \pm 2.46 \%)$ increased compared with the control group $(\mathrm{P}<0.05)$ (Fig. 3).
Effect of ginsenoside Rg1 on the expression levels of Bax, $B c l-2$, cleaved caspase- 3 and $p$-Akt. The results of the western blot assay indicated that the protein expression levels of cleaved caspase-3 were significantly upregulated in the $\mathrm{H}_{2} \mathrm{O}_{2}$ model group compared with the control group (Fig. 4; $\mathrm{P}<0.05$ ). Increased expression of $\mathrm{Bax}$ and reduced expression of Bcl-2 were observed in the $\mathrm{H}_{2} \mathrm{O}_{2}$-treated cells compared with the control group (Fig. 4; $\mathrm{P}<0.05$ ). Further 
A
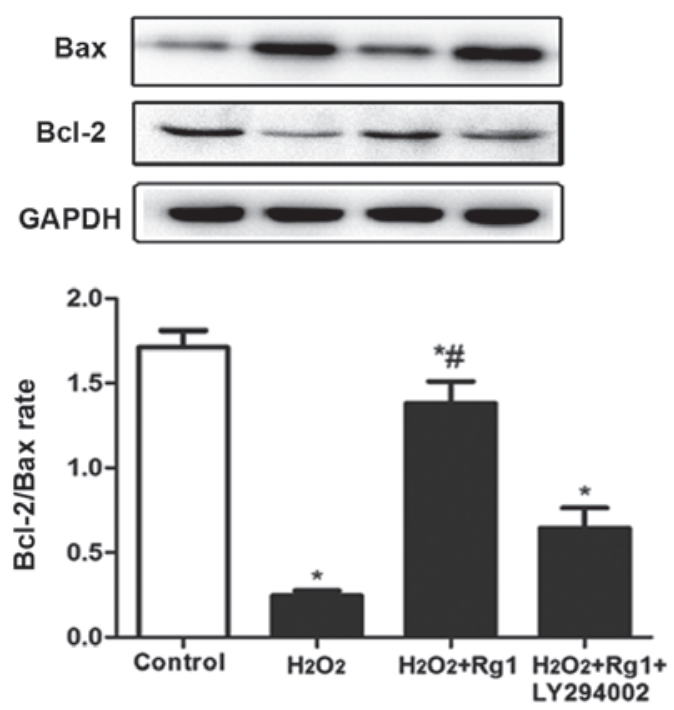

C

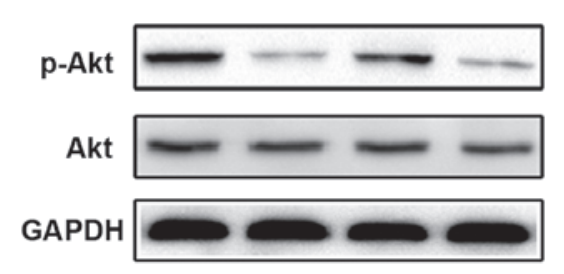

B
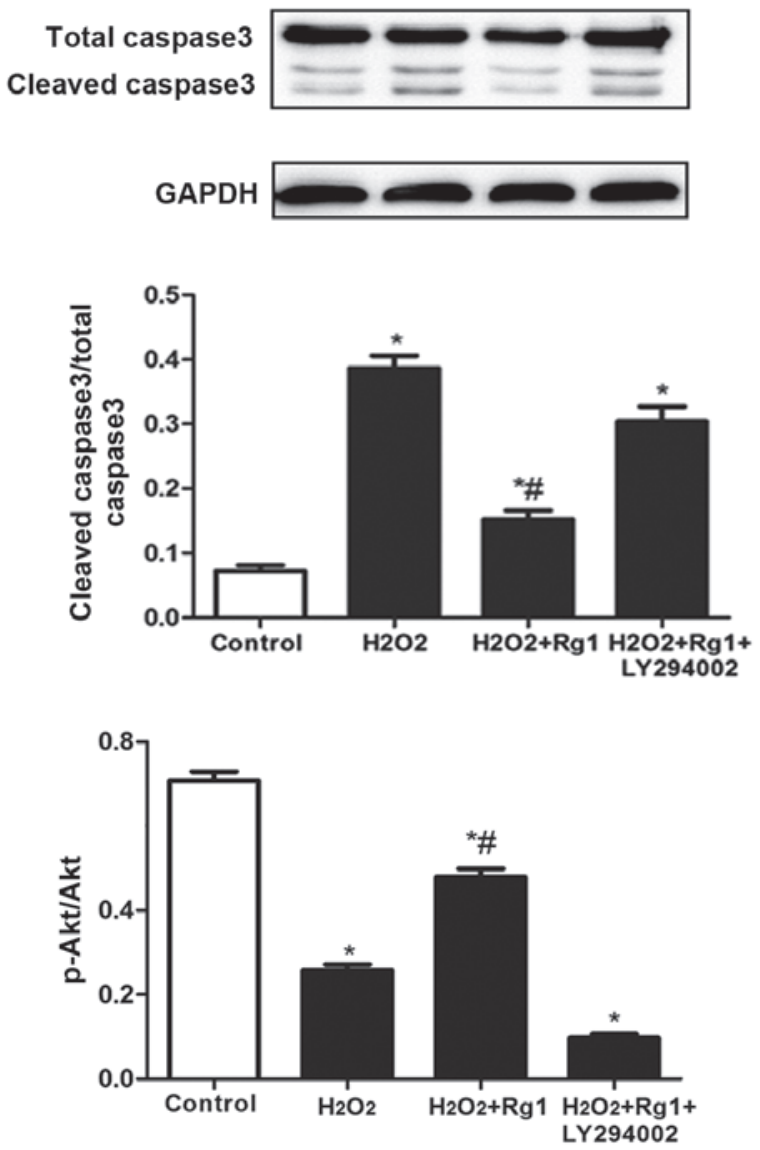

Figure 4. Detection of Bcl-2, Bax, caspase-3, p-Akt and Akt protein expression levels in $\mathrm{H}_{2} \mathrm{O}_{2}-$, Rg1- and LY294002-treated rat bone marrow stem cells. Western blotting was utilized to analyze (A) Bcl-2 and Bax, (B) total/cleaved caspase-3, and (C) p-Akt and Akt protein expression levels. GAPDH was used as a loading control. Results are presented as the ratio of (A) Bax to Bcl-2, (B) caspase-3 to GAPDH and (C) p-Akt to Akt. Data are presented as the mean \pm standard error of the mean $(n=3)$. ${ }^{*} \mathrm{P}<0.05$ vs. the control group and ${ }^{\#} \mathrm{P}<0.05$ vs. the $\mathrm{H}_{2} \mathrm{O}_{2}$ model group and the $\mathrm{H}_{2} \mathrm{O}_{2}+\mathrm{Rg} 1+\mathrm{LY} 294002$ group. p-, phosphorylated; Akt, protein kinase $\mathrm{B} ; \mathrm{H}_{2} \mathrm{O}_{2}$, hydrogen peroxide; $\mathrm{Rg}$ 1, ginsenoside Rg1; GAPDH, glyceraldehyde 3-phosphate dehydrogenase.

treatment with ginsenoside Rg1 significantly prevented the upregulation of Bax and the downregulation of $\mathrm{Bcl}-2$, while LY294002 treatment increased the ratio of $\mathrm{Bax} / \mathrm{Bcl}-2$, compared with the $\mathrm{H}_{2} \mathrm{O}_{2}$-treated group (Fig. 4; $\mathrm{P}<0.05$ ). The expression levels of Bax and cleaved caspase- 3 were significantly reduced in the ginsenoside $\mathrm{Rg} 1$ treatment groups compared with the $\mathrm{H}_{2} \mathrm{O}_{2}$ model group, while the expression levels of $\mathrm{Bcl}-2$ and $\mathrm{p}$-Akt were significantly upregulated (Fig. 4; $\mathrm{P}<0.05$ ). No statistical significance was observed between the LY294002-treated and $\mathrm{H}_{2} \mathrm{O}_{2}$-treated groups in terms of protein expression (Fig. 4; $\mathrm{P}>0.05$ ).

\section{Discussion}

BMSCs are known as 'seeds' in cell replacement therapy and tissue engineering due to their strong proliferation and multi-directional differentiation potential. BMSCs transplantation therapy has attracted increasing attention. A previous study demonstrated that the hypoxic-ischemic tissues and high oxidative stress resulting from ischemia-reperfusion injury have an adverse impact on the survival of BMSCs in the transplantation area (23). As a result, the effect of BMSC transplantation in CRT is reduced. The marked accumulation of ROS may alter the redox state of the cells. Cells, tissues and organs undergo various injuries through the oxidation of DNA, proteins, lipids and other biomacromolecules. Excess ROS increase the permeability of the mitochondrial outer membrane, inducing the leakage of cytochrome $c$ and apoptosis-inducing factors, thus this results in cell apoptosis. Therefore, it is necessary to reduce the oxidative stress in the transplantation region and to inhibit the apoptosis of BMSCs under oxidative stress.

Ginsenoside $\operatorname{Rg} 1$ is a phytoestrogen (28), exhibiting anti-oxidative and anti-apoptotic potential in myocardial cells and nerve cells $(29,30)$. However, it remains to be reported whether ginsenoside $\operatorname{Rg} 1$ has an antagonist effect against the apoptosis of BMSCs. To verify the anti-oxidative effect of ginsenoside Rg1 in BMSCs, the cells were pretreated with different concentrations of ginsenoside $\operatorname{Rg} 1(1-100 \mu \mathrm{M})$ for $24 \mathrm{~h}$ prior to $\mathrm{H}_{2} \mathrm{O}_{2}$ treatment. The results of the CCK- 8 assay indicated that ginsenoside Rg1 pretreatment significantly improved the survival of rBMSCs under oxidative stress. To further confirm the anti-apoptotic effect of ginsenoside Rg1 in BMSCs, the apoptosis of rBMSCs was determined using flow cytometry and TUNEL staining under $\mathrm{H}_{2} \mathrm{O}_{2}$-induced oxidative stress. The results indicated that under high oxidative stress, the pretreatment of $10 \mu \mathrm{M}$ ginsenoside $\mathrm{Rg} 1$ effectively reversed the $\mathrm{H}_{2} \mathrm{O}_{2}$-induced apoptosis of BMSCs. 
Bcl-2 is an anti-apoptotic protein that acts to prevent apoptosis by inhibiting mitochondrial depolarization (31). Bax belongs to the same family as Bcl-2 and is a pro-apoptotic protein that induces apoptosis by promoting mitochondrial depolarization (32). The initiation of apoptosis is associated with the activation of promoters and the protease cascade reaction. During the protease cascade process, caspase- 3 is the primary executor of apoptosis $(33,34)$ and the downstream effector protein of several apoptotic pathways. The present study aimed to reveal the protective mechanism of ginsenoside Rg1 against the apoptosis of BMSCs under oxidative stress, thus the expression levels of apoptosis-associated proteins were detected using western blot analysis. The results indicated that $\mathrm{H}_{2} \mathrm{O}_{2}$-induced oxidative stress increased the intracellular expression levels of Bax and cleaved caspase-3, while reducing the expression of Bcl-2. In addition, ginsenoside Rg1 pretreatment significantly reversed this phenomenon. This further indicates that the anti-apoptotic mechanism of ginsenoside Rg1 may be associated with the inhibition of apoptotic proteins involved in the mitochondrial pathways.

The PI3K/Akt signaling pathway is one of the most important pathways discovered to be associated with cell survival $(21,35)$. Certain stimuli activate the pathway and promote cell survival, the activated Akt is then directly involved in the regulation of cell growth, proliferation and the cell cycle (36). It exhibits an anti-apoptotic effect by enhancing the expression levels of anti-apoptotic proteins and by inhibiting the expression levels of pro-apoptotic proteins (37). Preliminary experiments of a previous study demonstrated that ginsenoside $\mathrm{Rg} 1$ inhibited the apoptosis of rat chondrocytes by activating the Akt signaling pathway (30). However, it remains unclear whether BMSCs apoptosis may be inhibited by ginsenoside $\operatorname{Rg} 1$ activating the PI3K/Akt pathway. The results of the current study demonstrated that ginsenoside $\mathrm{Rg} 1$ pretreatment effectively reversed the $\mathrm{H}_{2} \mathrm{O}_{2}$-induced downregulation of $\mathrm{p}$-Akt, significantly increased the expression of Bcl-2 and inhibited the expression of Bax and cleaved caspase-3. In order to verify the role of the PI3K/Akt pathway in the anti-apoptotic effect of ginsenoside Rg1 in BMSCs, LY294002, the specific PI3K inhibitor was administered. The results indicated that the antagonistic capacity of ginsenoside Rg1 against $\mathrm{H}_{2} \mathrm{O}_{2}$-induced apoptosis was inhibited. This confirmed the importance of the PI3K/Akt pathway in the protective effect of ginsenoside $\operatorname{Rg} 1$ against the apoptosis of BMSCs.

In addition, only the proteins associated with the mitochondrial apoptosis pathway were detected, and cell apoptosis may be additionally associated with the death receptor (36) and endoplasmic reticulum pathways (37). In conclusion, ginsenoside $\mathrm{Rg} 1$ was demonstrated to possess an antagonistic effect against the oxidative stress-induced apoptosis of BMSCs, and the specific mechanism may be associated with the activation of the PI3K/Akt pathway.

\section{References}

1. Song IH, Caplan AI and Dennis JE: In vitro dexamethasone pretreatment enhances bone formation of human mesenchymal stem cells in vivo. J Orthop Res 27: 916-921, 2009.
2. Granero-Moltó F, Weis JA, Miga MI, Landis B, Myers TJ, O'Rear L, Longobardi L, Jansen ED, Mortlock DP and Spagnoli A: Regenerative effects of transplanted mesenchymal stem cells in fracture healing. Stem Cells 27: 1887-1898, 2009.

3. Chen WJ, Huang JW, Niu CC, Chen LH, Yuan LJ, Lai PL, Yang CY and Lin SS: Use of fluorescence labeled mesenchymal stem cells in pluronic F127 and porous hydroxyapatite as a bone substitute for posterolateral spinal fusion. J Orthop Res 27: 1631-1636, 2009.

4. Bacigaluppi M, Pluchino S, Martino G, Kilic E and Hermann DM: Neural stem/precursor cells for the treatment of ischemic stroke. J Neurol Sci 265: 73-77, 2008.

5. Tang YL, Zhao Q, Zhang YC, Cheng L, Liu M, Shi J, Yang YZ, Pan C, Ge J and Phillips MI: Autologous mesenchymal stem cell transplantation induce VEGF and neovascularization in ischemic myocardium. Regul Pept 117: 3-10, 2004.

6. Kaminski A and Steinhoff G: Current status of intramyocardial bone marrow stem cell transplantation. Semin Thorac Cardiovasc Surg 20: 119-125, 2008

7. Wei H, Li Z, Hu S, Chen $X$ and Cong X: Apoptosis of mesenchymal stem cells induced by hydrogen peroxide concerns both endoplasmic reticulum stress and mitochondrial death pathway through regulation of caspases, p38 and JNK. J Cell Biochem 111: 967-978, 2010.

8. Muthusami S, Ramachandran I, Muthusamy B, Vasudevan G Prabhu V, Subramaniam V, Jagadeesan A and Narasimhan S: Ovariectomy induces oxidative stress and impairs bone antioxidant system in adult rats. J Clin Chim Acta 360: 81-86, 2005.

9. Kadenbach B, Ramzan R and Vogt S: Degenerative diseases, oxidative stress and cytochrome c oxidase function. Trends Mol Med 15: 139-147, 2009.

10. Lee GJ, Chae SJ, Jeong JH, Lee SR, Ha SJ, Pak YK, Kim W and Park HK: Characterization of mitochondria isolated from normal and ischemic hearts in rats utilizing atomic force microscopy. Micron 42: 299-304, 2011.

11. Schaller S, Paradis S, Ngoh GA, Assaly R, Buisson B, Drouot C, Ostuni MA, Lacapere JJ, Bassissi F, Bordet T, et al: TRO40303, a new cardioprotective compound, inhibits mitochondrial permeability transition. J Pharmacol Exp Ther 333: 696-706, 2010.

12. Chen H-Y, Zhang X, Chen S-F, Zhang Y-X, Liu Y-H, Ma LL and Wang LX: The protective effect of $17 \beta$-estradiol against hydrogen peroxide-induced apoptosis on mesenchymal stem cell. Biomed Pharmacother 66: 57-63, 2012.

13. Wang J, Zhang P, Dai QG, Ouyang NJ, Jiang LY and Fang B: The effect of estrogen on proliferation and osteogenic differentiation of rat bone marrow mesenchymal stem cells. Shanghai Kou Qiang Yi Xue 23: 654-660, 2014 (In Chinese).

14. Zhou S, Zilberman Y, Wassermann K, Bain SD, Sadovsky $\mathrm{Y}$ and Gazit D. Estrogen modulates estrogen receptor alpha and beta expression, osteogenic activity, and apoptosis in mesenchymal stem cells (MSCs) of osteoporotic mice. J Cell Biochem Suppl (Suppl 36): 144-155, 2001.

15. Hamden K, Carreau S, Ayadi F, Masmoudi H and El Feki A: Inhibitory effect of estrogens, phytoestrogens, and caloric restriction on oxidative stress and hepato-toxicity in aged rats. Biomed Environ Sci 22: 381-387, 2009.

16. Aneja R, Upadhyaya G, Prakash S, Dass SK and Chandra R: Ameliorating effect of phytoestrogens on CCl4-induced oxidative stress in the livers of male Wistar rats. Artif Cells Blood Substit Immobil Biotechnol 33: 201-213, 2005.

17. Chen XC, Zhou YC, Chen Y, Zhu YG, Fang F and Chen LM: Ginsenoside $\operatorname{Rg} 1$ reduces MPTP-induced substantia nigra neuron loss by suppressing oxidative stress. Acta Pharmacol Sin 26: 56-62, 2005.

18. Ma J, Liu J, Wang Q, Yu H, Chen Y and Xiang L: The beneficial effect of ginsenoside Rg1 on Schwann cells subjected to hydrogen peroxide induced oxidative injury. Int J Biol Sci 9: 624-636, 2013

19. Zhu D, Wu L, Li CR, Wang XW, Ma YJ, Zhong ZY, Zhao HB, Cui J, Xun SF, Huang XL, et al: Ginsenoside Rg1 protects rat cardiomyocyte from hypoxia/reoxygenation oxidative injury via antioxidant and intracellular calcium homeostasis. J Cell Biochem 108: 117-124, 2009.

20. Gong L, Li SL, Li H and Zhang L: Ginsenoside Rg1 protects primary cultured rat hippocampal neurons from cell apoptosis induced by $\beta$-amyloid protein. Pharm Biol 49: 501-507, 2011.

21. Sen P, Mukherjee S, Ray D and Raha S: Involvement of the Akt/PKB signaling pathway with disease processes. Mol Cell Biochem 253: 241-246, 2003. 
22. Khor TO, Gul A, Ithnin $\mathrm{H}$ and Seow HF: Positive correlation between overexpression of phospho-BAD with phosphorylated Akt at serine 473 but not threonine 308 in colorectal carcinoma. Cancer Lett 210: 139-50, 2004.

23. Sun B, Feng M, Tian X, Lu X, Zhang Y, Ke X, Huang S, Cao J and Ding X: DL-3-n-Butylphthalide protects rat bone marrow stem cells against hydrogen peroxide-induced cell death through antioxidation and activation of PI3K-Akt pathway. Neurosci Lett 516:247-252, 2012.

24. Lu WY and Zhao MF: Effect of oxidative stress on bone marrow mesenchymal stem cells. (Article in Chinese) Zhongguo Yi Xue Ke Xue Yuan Xue Bao 34: 90-94, 2012.

25. Lv C, Hao Y, Han Y, Zhang W, Cong L, Shi Y and Tu G. Role and mechanism of microRNA-21 in H2O2-induced apoptosis in bone marrow mesenchymal stem cells. J Clin Neurosci: Jan 22, 2016 (Epub ahead of print).

26. Wang XY, Fan XS, Cai L, Liu S, Cong XF and Chen X: Lysophosphatidic acid rescues bone mesenchymal stem cells from hydrogen peroxide-induced apoptosis. Apoptosis 20: 273-284, 2015.

27. Zeng X, Yu SP, Taylor T, Ogle M and Wei L: Protective effect of apelin on cultured rat bone marrow mesenchymal stem cells against apoptosis. Stem Cell Res 8: 357-367, 2012.

28. Gao QG, Chan HY, Man CW and Wong MS: Differential $\mathrm{ER} \alpha$-mediated rapid estrogenic actions of ginsenoside Rg1 and estren in human breast cancer MCF-7 cells. J Steroid Biochem Mol Biol 141: 104-112, 2014.
29. González-Burgos, Fernandez-Moriano C, Gómez-Serranillos MP: Potential neuroprotective activity of Ginseng in Parkinson's Disease: A review. J Neuroimmune Pharmacol 10, 2015.

30. Huang Y, Wu D and Fan W: Protection of ginsenoside Rg1 on chondrocyte from IL-1 $\beta$-induced mitochondria-activated apoptosis through PI3K/Akt signaling. Mol Cell Biochem 392: 249-257, 2014.

31. Shi Y: A structural view of mitochondria-mediated apoptosis. Nat Struct Biol 8: 394-401, 2001

32. Narita M,Shimizu S,Ito T, Chittenden T, Lutz RJ, Matsuda H and Tsujimoto Y: Bax interacts with the permeability transition pore to induce permeability transition and cytochrome c release in isolated mitochondria. Proc Natl Acad Sci USA 95:14681-14686, 1998.

33. Odonkor CA and Achilefu S: Modulation of effector caspase cleavage determines response of breast and lung tumor cell lines to chemotherapy. Cancer Invest 27: 417-429, 2009.

34. Lin HH, Chen JH, Huang CC and Wang CJ: Apoptotic effect of 3,4-dihydroxybenzoic acid on human gastric carcinoma cells involving JNK/p38 MAPK signaling activation. Int J Cancer 120: 2306-2316, 2007.

35. Matsui T, Li L, Wu JC, Cook SA, Nagoshi T, Picard MH, Liao R and Rosenzweig A: Phenotypic spectrum caused by transgenic overexpression of activated Akt in the heart. J Biol Chem 277: 22896-22901, 2002

36. Sussman M: 'AKT'ing lessons for stem cells: Regulation of cardiac myocyte and progenitor cell proliferation. Trends Cardiovasc Med 17: 235-240, 2007.

37. Downward J: PI 3-kinase, Akt and cell survival. Semin Cell Dev Biol 15: 177-182, 2004. 